\title{
Krzysztof Jasiecki
}

\section{Polityka publiczna wobec kapitału zagranicznego. Kapitalizm zależny?}

\begin{abstract}
Streszczenie
Autor analizuje wybrane cechy kapitalizmu w państwach Europy Środkowej. Opisuje różne koncepcje teoretyczne tego zagadnienia, w tym podejście sformułowane przez L. Kinga i I. Szelenyi’ego, które zakłada, że zmiany systemowe w państwach tego regionu szczególnie adekwatnie charakteryzuje perspektywa kapitalizmu „z zewnątrz” (from without). Ukazuje ona jego specyfikę w tym, że w kluczowym okresie pokomunistycznych zmian ustrojowych występowało zjawisko absencji znaczących klas prywatnych właścicieli, którzy na Zachodzie byli głównymi promotorami gospodarki rynkowej.

Artykuł wskazuje zalety i wady modelu gospodarczego uformowanego przez dominujący udział kapitału zagranicznego, zwłaszcza będące konsekwencją tego zjawiska ograniczenia podmiotowości polityki gospodarczej państwa oraz szans rozwojowych rodzimego biznesu. Charakteryzuje obawy, że model ten ukształtowany w Polsce (i innych państwach regionu) po 1989 r. wyznacza krajowym przedsiębiorstwom role korporacyjnych poddostawców, głównie tradycyjnych lub niszowych produktów oraz usług.
\end{abstract}

Słowa kluczowe: socjologia ekonomiczna, transformacja, państwo, kapitalizm zależny, kapitał transnarodowy, bezpośrednie inwestycje zagraniczne.

\section{Public policy in relation to foreign capital. Dependent capitalism?}

\begin{abstract}
The author analyses the selected aspects of capitalism in the countries of Central Europe. The author presents the various theoretical concepts that refer to the issue in question involving the concept coined by L. King and I. Szelenyi, which holds that the systemic changes in the countries of this region are specifically characterised by the perspective of 'from without' capitalism. They believe that the specificity of the capitalist system lies in the fact that in the key times of the post-communist changes of the political system, the issue of the absence of an important class of private owners was not addressed. In
\end{abstract}


the West private proprietors were the ones that constituted the main driving force of an open-market economy.

The article presents the advantages and drawbacks of an economic model formed by the dominant share of foreign capital, with an emphasis placed on the consequences of the issue in question on the limitations of the subjectivity of economic policy of a state as well as the development chances of local businesses. It manifests the fears that the model created in Poland (and in other countries of the region) after the year 1989 sets the role model for local enterprises of corporate subcontractors of mainly traditional or niche products and services.

Keywords: economic sociology, transformation, the state, dependent capitalism, transnational capital, foreign direct investment.

Zdaniem L. Kinga i I. Szelenyi'ego ${ }^{1}$ zmiany systemowe w europejskich państwach posocjalistycznych charakteryzuje adekwatnie koncepcja kapitalizmu „Z zewnątrz” (from without), która zwraca uwagę na kluczową rolę w tym procesie reguł transferowanych z Unii Europejskiej oraz aktywności inwestorów zagranicznych. Koncepcja ta koncentruje się na zagadnieniach stosunkowo rzadko w Polsce badanych - regulacyjnego i strukturotwórczego wpływu kapitału zagranicznego na kształt instytucji gospodarczych oraz przekształceń społecznych. Jej punktem wyjścia stała się konstatacja, że differentia specifica nowego ładu systemowego w państwach postkomunistycznych była początkowa absencja klas prywatnych właścicieli, na Zachodzie będących historycznie głównymi promotorami gospodarki rynkowej.

W takich okolicznościach za najlepszą metaforę odmienności transformacji w Europie Środkowej uznano tworzenie „kapitalizmu bez kapitalistów”, realizowane w warunkach rozszerzenia UE na Wschód ${ }^{2}$. Badacze zwracają uwagę na związki pomiędzy globalizacją a przekształceniami strukturalnymi na poziomie krajowym³. Generują one bowiem szczególnie znaczące zmiany równowagi sił w społeczeństwie,

1 L.P. King, I. Szelenyi, Post-Communist Economic Systems, w: The Handbook of Economic Sociology, red. J.N. Smelser, R. Swedberg, Princeton University Press, Princeton 2005, s. 205-229.

2 G. Eyal, I. Szelenyi, E. Townsley, Making Capitalism Without Capitalists: Class Formation and Elite Struggles in Post-Communist Europe, Verso, London 1998.

3 Ivan Szelenyi zainicjował i koordynował wiele projektów badawczych nad stratyfikacją i mobilnością społeczną w krajach postkomunistycznych, był m.in. inicjatorem i współautorem szeroko dyskutowanych w latach 90. publikacji dotyczących wymiany oraz reprodukcji elit (por. I. Szelenyi, D. Treinman, E. Wnuk-Lipiński, Elity w Polsce, w Rosji i na Wegrzech. Wymiana czy reprodukcja, Instytut Studiów Politycznych PAN, Warszawa 1995). Por. także, L.P. King, Central European Capitalism in Comparative Perspective, w: Beyond Varieties of Capitalism. Conflict, Contradictions, and Complementarities in the European Economy, red. B. Hancké, M. Rhodes, M. Thatcher, Oxford University Press, Oxford 2007, s. 308-327. 
w tym nowy podział władzy, reguły stratyfikacji i redystrybucji zasobów ${ }^{4}$ W Polsce takie związki wydają się tym bardziej godne uwagi w badaniach nad rozwojem kapitalizmu, że stosunkowo długo były one słabo dostrzegane. Przesłaniała je początkowo wyjątkowa rola Solidarności w zmianach ustrojowych i duża dynamika wewnętrznych przekształceń instytucjonalnych, a wpływy aktorów zewnętrznych na tym etapie zmian uznawano za mniej znaczące ( $\mathrm{z}$ wyjątkiem sfery stosunków międzynarodowych umożliwiających „wybicie się na niepodległość”).

Od połowy lat 90. zaczęła jednak w tym zakresie następować stopniowa ewolucja zainteresowań badawczych i akcentów kładzionych w refleksji socjologicznej. Przebieg radykalnych reform gospodarczych, których częścią było otwarcie Polski na kapitał zachodni, a później dostosowania do regulacji unijnych wraz z poprawą sytuacji ekonomicznej państwa spowodowały, że zaczął się istotny napływ inwestycji zagranicznych. Taki kierunek przemian przekładał się na przyspieszenie zmian również w innych sferach życia społecznego, m.in. wchodzenia nowych podmiotów sfery prywatnej w postaci korporacji transnarodowych, tworzenia się innych rodzajów racjonalności, motywacji i interesów, a także kryteriów oceny przekształceń ustrojowych. Transformacja posocjalistyczna była też coraz częściej postrzegana jako ściśle powiązana z procesem integracji europejskiej ${ }^{5}$, co sprzyjało podejmowaniu badań porównawczych i interdyscyplinarnych, inspirujących rozwój nowych dyscyplin, jak na przykład studiów europejskich oraz europeistyki.

\section{„Kapitalizm bez kapitalistów" i kapitaliści kulturowi}

W Polsce i innych państwach Europy Środkowej i Wschodniej strukturalnie najistotniejszą konsekwencją niedokończonej kapitalistycznej industrializacji w XIX w. oraz późniejszej socjalistycznej modernizacji, stała się nieobecność kluczowych dla gospodarki rynkowej aktorów społecznych - klas prywatnych właścicieli, a także

4 Zob. analizy wpływu globalizacji i integracji europejskiej na mechanizmy stratyfikacyjne w różnych państwach, które przeprowadzają H. Domański i A. Prokopek, Podziały terytorialne, globalizacja a nierówności społeczne. Wprowadzenie do modeli wielopoziomowych, Instytut Filozofii i Socjologii PAN, Warszawa 2011. Na forum międzynarodowym silnym impulsem dla tego typu analiz stały się badania Esping-Andersena dotyczące państwa opiekuńczego jako systemu stratyfikacji społecznej. Por. także L. Kenworthy, Institutions, Wealth, and Inequality, w: The Oxford Handbook of Comparative Institutional Analysis, red. G. Morgan, J. Campbell, C. Crouch, O. Kay Pedersen, R. Whitley, Oxford University Press, Oxford 2010, s. 399-420; M. Mann, D. Riley, Explaining macro-regional trends in global income inequalities, 1950-2000, "Socio-Economic Review" 2007, no. 5, s. 81-115.

5 Przejawem takiej orientacji była m.in. seria raportów monitorujących integrację Polski z UE, w których opracowaniu brali udział przedstawiciele różnych dyscyplin naukowych. Zob. M. Belka, J. Hausner, L.J. Jasiński, M. Marody, M. Zirk-Sadowski, Polska transformacja w perspektywie integracji europejskiej. EU-monitoring, Friedrich Ebert Foundation, Warszawa 1996. 
grup interesu, partii politycznych i mediów, które miały wyrażać ich interesy. Taka sytuacja miała wiele ważnych implikacji teoretycznych oraz pragmatycznych. Głównym postulatem neoliberalnych reformatorów stało się upodobnienie struktury społecznej Polski do zachodnich „społeczeństw klasy średniej”. Nadzieje na szybkie powstanie klasy średniej (zgodnie z teorią modernizacji stanowiącej przejaw takiego kierunku zmian), nie znalazły jednak potwierdzenia w praktyce społecznej. Takie przekształcenia mają bowiem charakter długookresowy, a formowanie się nowych segmentów struktury społecznej wymaga zwykle kilku pokoleń.

Zastanawiano się zatem, jak zdefiniować strategicznych aktorów transformacji, tj. klasy lub warstwy społeczne stanowiące główną siłę motoryczną przemian systemowych, kształtujące w największej mierze przyszłość społeczeństwa ${ }^{6}$. Socjologowie wyróżniają podmioty o różnej „mocy transformacyjnej”, dysponujące odmiennymi zasobami i stopniem wpływu na procesy polityczne. W schyłkowym okresie socjalizmu państwowego głównymi dysponentami takiej mocy były elity polityczne, które inicjowały zmiany ustrojowe, uruchamiające radykalne przekształcenia instytucjonalne i strukturalne. Odzwierciedleniem takiej sytuacji stał się renesans teorii elit oraz liczne badania nad ich rolą w konstruowaniu i wprowadzaniu nowych reguł systemowych ${ }^{7}$. Równocześnie charakteryzowano także szybko zachodzące zmiany wewnątrz „starych” i „nowych” elit. Profesjonalizacja polityki zmniejszała znaczenie byłych dysydentów, wypieranych przez technokratów i nowych biurokratów, których kwalifikacje ekonomiczne lub menedżerskie stawały się atutem w zmianach na szczytach władzy. J. Wasilewski taką ewolucję charakteryzował jako przejście od elity przełomu - dokonującej strategicznych wyborów, poprzez elitę transformacji - skupiającą się na realizacji reform, do elity konsolidacji, której głównym zadaniem stało się usprawnianie ukształtowanego nowego ładu instytucjonalnego.

Ewolucja roli elit miała odmienny przebieg w środowiskach gospodarczych. Występowały czynniki hamujące jej rozwój - początkowa koncentracja na tworzeniu własnych firm, niewielka skala prowadzonej działalności, indywidualizm przedsiębiorców i słabość reprezentacji pracodawców. Rodzime elity gospodarcze nie miały możliwości odgrywania znaczącej roli w relacjach z „klasą polityczną” (co nie wykluczało istotnych wpływów niektórych przedsiębiorców, np. w zakresie decyzji prywatyzacyjnych). W końcu lat 90. pojawiły się jednak wyraźne symptomy wzrostu

6 A. Kolasa-Nowak, Zmiana systemowa $w$ Polsce $w$ interpretacjach socjologicznych, Wydawnictwo Uniwersytetu Marii Skłodowskiej-Curie, Lublin 2010, s. 84-85.

7 Restructuring of the economic elites after state socialism: recruitment, institutions and attitudes, red. D. Lane, G. Lengyel, J. Tholen, ibidem-Verlag, Stuttgart 2007; Elites after state socialism. Theories and analysis, red. J. Higley, G. Lengyel, Rowman \& Littlefield Publishers, Boston 2000.

8 J. Wasilewski, Elitystyczne wyjaśnienia wschodnioeuropejskich demokratyzacji, w: Populizm a demokracja, red. R. Markowski, Instytut Studiów Politycznych PAN, Warszawa 2004, s. 69-94. 
znaczenia i wpływów środowisk gospodarczych w relacjach ze światem polityki, czego symptomem stało się m.in. przechodzenie od klientelizmu środowisk gospodarczych w stosunku do świata polityki do tworzenia powiązań oligarchicznych, ujawnionych spektakularnie przez „aferę Rywina”. Największe możliwości wpływu elit dotyczą jednak relatywnie krótkich okresów zmian ustrojowych, sytuacji rewolucyjnych czy konfliktów zbrojnych.

Wprowadzanie demokratycznych instytucji politycznych wymagało poszukiwania zaplecza dla polityki reform, także w innych środowiskach społecznych. Wśród socjologów przeważał pogląd, że tworzenie gospodarki rynkowej dowartościowuje przede wszystkim dysponentów kapitału kulturowego - inteligencję, która w Europie Centralnej początkowo stanowiła częściowy ekwiwalent deficytowego kapitału ekonomicznego. Z czasem sformułowano tezę, że obok elit władzy za głównego zbiorowego „aktora” zmian zainteresowanego w przeprowadzeniu transformacji kapitalistycznej można uznać inteligencję. G. Eyal, I. Szelenyi i E. Townsley ${ }^{9}$ liczyli na powstanie „postkomunistycznego menedżeryzmu”, który przekształci tę specyficzną dla Europy Wschodniej warstwę społeczną w funkcjonalny odpowiednik zachodniej burżuazji. Dla jej opisu używano również pojęć „nowa technokracja” lub „nowa klasa”, a jej rdzeniem mieliby być menedżerowie i wykształceni profesjonaliści. Ich formowanie się i role rozpatrywano jako symptom początków ewolucji inteligencji w kierunku rynkowej knowledge class ${ }^{10}$ lub porównywano do zachodniej service class ${ }^{11 .}$

Analizy socjologicznych interpretacji zmian ustrojowych w Polsce prowadzą do wniosku, że duża dynamika przekształceń instytucjonalnych i strukturalnych, rozbieżności interesów oraz słabość czynników scalających, spowodowały szybką erozję oraz rozproszenie zbiorowych aktorów społecznych. Powyższe uwagi dotyczą zwłaszcza klasy robotniczej i chłopskiej, które uległy fragmentacji oraz marginalizacji. Miejsce takich „znikających aktorów” zaczęli zajmować inni aktorzy o odmiennych zasobach i sile działania - nowe elity polityczne, w tym samorządowe, niektóre segmenty środowisk biznesu, stare i nowe grupy interesu (zawodowe, branżowe, problemowe, regionalne, lokalne itd.) lub podmioty w mikroskali, m.in. przedsiębiorcy i konsumenci ${ }^{12}$. Ze względu na wczesną fazę tworzenia się klas średnich, niską kulturę obywatelską i dużą atomizację społeczną, większość Polaków jest jednak słabo zorganizowana i w niewielkim zakresie wpływa na kształt polityki publicznej.

9 G. Eyal, I. Szelenyi, E. Townsley, op.cit.

${ }^{10} \mathrm{H}$. Domański, Klasy społeczne, grupy zawodowe, organizacje gospodarcze, Instytut Filozofii i Socjologii PAN, Warszawa 1991.

${ }^{11}$ H. Best, Cadres into Managers: Structural Changes of East German Economic Elites before and after Reunification, w: Restructuring of the economic elites..., op.cit., s. 27-44.

12 A. Kolasa-Nowak, op.cit., s. 84-89. 


\section{Słaba przeciwwaga wobec interesów kapitału zagranicznego}

Zdaniem Kinga i Szelenyiego strategie polityczne nowych elit przejmujących władzę w Polsce, na Węgrzech i w Czechosłowacji początkowo były zbliżone. U schyłku socjalizmu państwowego opozycyjni dysydenci wraz z częścią krytycznych technokratów tworzyli mniej lub bardziej sformalizowany sojusz przeciwko rządzącej biurokracji partyjnej i administracji państwowej („nomenklaturze”). Po zmianie systemowej na krótko doszło do „rządów zgody narodowej”, lecz szybko nastąpiła ewolucja dominującej ideologii oraz zmiany składu elit. „Rewolucja pożerała swoich przywódców".

W świetle tej koncepcji, w państwach naszego regionu nie wykrystalizowały się elity, ani tym bardziej struktura społeczna, która mogłaby stanowić efektywną przeciwwagę wobec interesów kapitału zagranicznego. Zwłaszcza, że inwestorzy zagraniczni zdobyli już po kilku latach dominującą pozycję w kluczowych sektorach gospodarki i stali się również głównym aktorem zmian w wielu innych sferach życia społecznego w Polsce oraz w większości państw regionu. Wynikało to zarówno ze słabości instytucji publicznych i krajowego biznesu, jak również ze specyficznej orientacji niektórych zbiorowych aktorów społecznych.

Wśród badaczy węgierskich dla scharakteryzowania nowej sytuacji przywołane zostało pojęcie „inteligencji kompradorskiej”, nawiązujące do tradycji latynoskiej teorii zależności. Charakteryzowało ono warstwę będącą częścią nowej elity władzy, która czerpała korzyści z pośrednictwa między instytucjami międzynarodowymi i instytucjami krajowymi. Jednym z jej kluczowych segmentów stali się menedżerowie sprzedający państwowe przedsiębiorstwa zagranicznym kontrahentom, którzy (w zamian za korzystne transakcje) zatrudniali ich na lukratywnych stanowiskach w przejmowanych firmach. Transnarodowe korporacje i organizacje gospodarcze uznały takie działania wobec menedżerów, a także wspierających ich funkcjonariuszy partyjnych i państwowych (różnych ugrupowań) za inwestycje, które przyspieszą internacjonalizację gospodarki. Posocjalistyczni technokraci przekształcali się w ten sposób w kapitalistycznych menedżerów pracujących dla inwestorów zagranicznych ${ }^{13}$.

${ }^{13}$ G. Eyal, I. Szelenyi, E. Townsley, op.cit., s. 173-175. Niektórzy socjologowie węgierscy, z którymi współpracowałem w projekcie The business elite of East Central Europe w końcu lat 90. twierdzili, jak np. P. Tamas, że trudno mówić o istnieniu autonomicznej węgierskiej elity biznesu, jeśli większość kluczowych firm tego kraju została przejęta przez kapitał zagraniczny. W 2004r. prawie 2/3 spośród podmiotów umieszczonych na liście 100 największych przedsiębiorstw działających na Węgrzech należało do zagranicznych właścicieli kontrolujących branże o największej dynamice rozwoju w bankowości, handlu, usługach i gałęziach przemysłu wysokiej techniki (M. Laki, Attitudes and Actions of the Members of the 
Czeski socjolog J. Drahokoupil używa wobec tej kategorii aktorów społecznych bardziej precyzyjnego określenia comprador service sector ${ }^{14}$.

Tworzą ją menedżerowie, eksperci, pracownicy i kooperanci firm oraz branż wykonujących usługi głównie dla inwestorów zagranicznych (od których są zależne ich dochody), m.in. zatrudniani w oddziałach globalnych instytucji finansowych oraz przedsiębiorstw z przeważającym udziałem kapitału zagranicznego. Wraz z częścią polityków i urzędników państwowych, sektor ten organizuje sieci współpracy oraz lobbing wspierający transnarodowe interesy. Przykładem występowania takich mechanizmów jest współdziałanie międzynarodowych korporacji tytoniowych z rodzimymi plantatorami tytoniu, którzy są zainteresowani utrzymywaniem dużego popytu na papierosy, uzasadnianego interesami ekonomicznymi (utrzymywaniem miejsc pracy, płaceniem podatków itd.).

Występowanie tego rodzaju tendencji stało się przedmiotem zainteresowania przedstawicieli socjologii historycznej, socjologii rozwoju oraz studiów regionalnych. W takiej perspektywie krytykowana była neoliberalna strategia „modernizacji przez integrację" z Zachodem, która zakładała, że w warunkach słabości rynku wewnętrznego, państwa i dopiero powstających klas średnich głównym źródłem zmian mogą być głównie instytucje międzynarodowe oraz inwestorzy zagraniczni ${ }^{15}$. Zdaniem M.S. Szczepańskiego wraz z procesem modernizacji „doszło do ugruntowania różnorakich form zależności” ${ }^{16}$. Można wśród nich wskazać: wprowadzenie reguł systemowych dających przewagę aktorom politycznym i gospodarczym z państw wysoko rozwiniętych, dostosowania akcesji do UE wiążące pomoc ekonomiczną ze spełnianiem narzuconych warunków (dalsza liberalizacja rynku wewnętrznego, prywatyzacja z udziałem kapitału zagranicznego itd.), układ europejski ograniczający dostęp polskiego eksportu na rynki unijne przy równoczesnym szybkim znoszeniu przez Polskę barier wobec importu z Zachodu, jak również rosnące uzależnienie zmian gospodarczych od czynników zewnętrznych - zwłaszcza napływu kapitału i technologii z zagranicy, a także zmian stosunków pracy w sposób zgodny z interesami

Hungarian Business Elites towards Foreign Owned Companies, w: Restructuring of the economic elites..., op.cit., s. 199-209). Jest to jedna z okoliczności sprzyjających narodowej retoryce Viktora Orbana, która częściowo stanowi reakcję na dominację kapitału zagranicznego w gospodarce węgierskiej, znacznie większą niż w wypadku Polski.

14 J. Drahokoupil, Globalization and The State in Central and Eastern Europe. The Politics of Foreign Direct Investment, Rutledge, London 2008.

15 J. Kochanowicz, Transformacja polska w świetle socjologii historycznej. Między Trzecim Światem a państwem opiekuńczym, „Kultura i Społeczeństwo” 1998, nr 1(42), s. 23-37; A. Sosnowska, Teorie zmiany i rozwoju społecznego a zmiany w Europie Wschodniej. O potrzebie perspektywy globalnej, „Kultura i Społeczeństwo" 1998, nr 1(42), s. 61-72.

${ }^{16}$ M.S. Szczepański, Ani Elizjum, ani Hades. Piętnastolecie polskiej transformacji w perspektywie socjologicznych teorii zmiany, w: Współczesne społeczeństwo polskie. Dynamika zmian, red. J. Wasilewski, Wydawnictwo Naukowe Scholar, Warszawa 2006, s. 27-28. 
inwestorów zagranicznych uznawanych za główny czynnik unowocześnienia gospodarki po zmianie ustrojowej. Procesy te można określić jako „modernizację zależności", której wyróżnikiem stało się dążenie do uzyskania członkostwa w UE z nadzieją, że stworzy ono w dłuższym okresie, m.in. dzięki funduszom unijnym i silnym powiązaniom z Zachodem, możliwości przeciwdziałania marginalizacji Polski w systemie światowym ${ }^{17}$.

\section{Napięcie interesów}

Krytycy neoliberalnych reform ostrzegali, że takie podejście może prowadzić do ograniczania suwerenności państwowej i możliwości rozwojowych gospodarki. Na tle tego rodzaju obaw, badacze rozpatrujący przemiany posocjalistyczne w świetle nowych teorii zależności centro-peryferyjnych akcentują dwoistość położenia elit naszego regionu Europy.

W tym kontekście dyskutowany jest m.in. problem uzależnienia części decydentów politycznych i innych grup lub warstw społecznych o strategicznym znaczeniu dla rozwoju państwa od zagranicznych źródeł finansowania. Zdaniem T. Zaryckiego ${ }^{18}$, dla niektórych segmentów krajowej elity „głównym pracodawcą, sponsorem i odbiorcą owoców ich pracy [...] są instytucje zagraniczne zlokalizowane w centrum". Podmioty zagraniczne dokonują także selekcji części elity ekonomicznej i klas średnich, pracujących w instytucjach publicznych lub firmach kontrolowanych przez obcy kapitał. Zewnętrzne preferencje stają się dla nich głównym układem odniesienia, otwierającym ścieżki lukratywnych karier (w korporacjach transnarodowych, administracji unijnej itd.).

Trzon takich nowych kategorii społecznych, opierających się głównie na kapitale kompetencji, składających się ze specjalistów w nowych dziedzinach wiedzy - informatyce, informacji gospodarczej, zarządzaniu i administrowaniu w skali ponadnarodowej oraz usługach biznesowych - jest czasem określany mianem „klasy metropolitarnej", bliskiej klasie kreatywnej w rozumieniu R. Florydy. Jej rdzeń tworzą warstwy społeczne i grupy zawodowe obsługujące w dużych aglomeracjach nowe instytucje sektora prywatnego, otoczenia gospodarki rynkowej oraz inwestorów

17 K. Jasiecki, Kapitalizm po polsku. Między modernizacja a peryferiami Unii Europejskiej, Instytut Filozofii i Socjologii PAN, Warszawa 2013.

${ }_{18}$ T. Zarycki, Peryferie. Nowe ujęcia zależności centro-peryferyjnych, Wydawnictwo Naukowe Scholar, Warszawa 2009, s. 62-64. 
zagranicznych ${ }^{19}$. W państwie przeznaczającym niewiele środków na naukę, badania, rozwój i kulturę, znaczna część elit politycznych, gospodarczych oraz kulturalnych znajduje się w sytuacji napięcia pomiędzy interesami narodowymi a interesami zagranicznymi lub transnarodowymi. Rodzi to dylematy wyboru i skrajne reakcje, w kierunku obrony własnego państwa przed domniemanymi wrogami czy też w przeciwstawnym wariancie, identyfikacji interesów Polski z interesami zachodnich i ponadnarodowych instytucji.

W takim kontekście niektórzy badacze zwracają uwagę na ukształtowanie się znanych z literatury międzynarodowej mechanizmów narastania niezależności gospodarki zdominowanej przez kapitał zagraniczny od kontroli państwa narodowego oraz jej oddalania się od społeczeństwa. Przesuwanie granicy między własnością prywatną a publiczną na korzyść sektora prywatnego sprzyja bowiem włączeniu części polskiej elity biznesu i klas średnich w ramy transnarodowej klasy kapitalistycznej, co niekoniecznie wzmacnia $\mathrm{w}$ beneficjentach takich powiązań motywacje do angażowania się w rozwój rodzimych instytucji i demokratycznych przemian społeczeństwa ${ }^{20}$.

\section{Dwie strategie rozwoju państwa}

T. Żukowski ${ }^{21}$ wyróżnił dwie zasadnicze strategie rozwoju państwa, odwołujące się do konkurencyjnych systemów wartości, zakorzenionych również w sferze interesów gospodarczych. Pierwszą, dominującą w latach 90., określił mianem „importowanej modernizacji”. Realizowały ją ugrupowania lewicowe i centrolewicowe, a także większość elit intelektualnych, biznes pośredniczący między klasą polityczną a kapitałem zagranicznym. Zwolennicy takiego podejścia w imię unowocześnienia państwa i zdynamizowania gospodarki sprzyjali przejęciu kontroli przez inwestorów

${ }^{19}$ Np. B.W. Mach, Jakość demokracji a struktura społeczna: uwagi koncepcyjne i ilustracje empiryczne, w: Jakość naszej demokracji. Społeczno-kulturowe podstawy polskiego życia publicznego, red. B.W. Mach, Instytut Studiów Politycznych PAN, Collegium Civitas, Warszawa 2012, s. 9-35. Na temat polskiej „klasy metropolitarnej", której wyróżnikiem statusowym oraz przestrzennym jest zamieszkiwanie w budownictwie apartamentowym i w grodzonych zespołach mieszkaniowych o wyższym standardzie (gates communities) na przykładzie Warszawy zob. Gettoizacja polskiej przestrzeni miejskiej, red. B. Jałowiecki, B. Łukowski, Wydawnictwo SWPS Academica - Wydawnictwo Naukowe Scholar, Warszawa 2007.

${ }^{20}$ Kontrowersje wokół roli transnarodowej elity biznesu charakteryzują m.in.: U. Beck, Władza i przeciwwładza w epoce globalnej. Nowa ekonomia polityki światowej, tłum. J. Łoziński, Wydawnictwo Naukowe Scholar, Warszawa 2005; S. Sassen, Globalizacja. Eseje o nowej mobilności ludzi i pieniędzy, tłum. J. Tegnerowicz, Uniwersytet Jagielloński, Kraków 2007; J. Drahokoupil, op.cit.; The Transnational Capitalist Class, Blackwell Publisher, Malden 2003; S.P. Huntington, Who are we? America's Great Debate, Simon \& Schuster, London 2004.

${ }^{21}$ T. Żukowski, Potęga tożsamości, w: System wartości i norm społecznych podstawą rozwoju Polski, Instytut Badań nad Gospodarką Rynkową, Gdańsk 2005, s. 74-96. 
zagranicznych w branżach generujących duże zyski (w bankowości, w telekomunikacji) oraz wspierali ich wchodzenie na obszary szczególnie znaczące dla rynku wewnętrznego, jak usługi konsultingowe, przemysł eksportowy, handel czy obrót nieruchomościami.

Natomiast druga strategia krystalizowała się od końcowego etapu negocjacji akcesyjnych z UE. Żukowski określił ją jako „polską drogę do modernizacji”. W jej ramach podejmowane są próby unowocześnienia konserwatywnych wartości i tożsamości odwołujących się do rodzimego kodu kulturowego i tradycji republikańskich, w tym zwłaszcza ruchu solidarnościowego. Jej głównymi orędownikami są politycy partii prawicowych i centroprawicowych, inteligencja zakorzeniona $\mathrm{w}$ tradycjach antykomunistycznych, niepodległościowych i patriotycznych, większość hierarchów Kościoła katolickiego, środowiska gospodarcze walczące o swoją pozycję na krajowym rynku (spółki skarbu państwa, małe i średnie przedsiębiorstwa), lobby prorodzinne, duża część wsi, małych miast na prowincji oraz konserwatywnej młodzieży ${ }^{22}$. Jednak nieudane próby wprowadzenia w latach 2005-2007 neokonserwatywnej „polskiej drogi do modernizacji” zakończone upadkiem rządu i przedterminowymi wyborami parlamentarnymi w znacznej mierze potwierdziły niektóre wcześniejsze prognozy ostrzegawcze formułowane pod jej adresem. „Najpoważniejszymi niebezpieczeństwami związanymi z "polską drogą do modernizacji« wydają się być dryf [...] ku formom jednoznacznie zamkniętym, swoistym »okopom samoobrony« oraz ryzyko politycznej nieskuteczności [...], mogącej prowadzić do dewastacji kulturowego zaplecza ruchu”23. W perspektywie możliwych zmian na scenie politycznej takie przewidywania zachowują swoją wartość, czego potwierdzeniem są również kontrowersje wokół polityki

22 Ibidem, s. 79. Zwolennicy ugrupowań prawicowych wiążą potrzebę radykalnej zmiany, przełamującej duchowe i instytucjonalne dziedzictwo komunizmu, z koniecznością odejścia od neoliberalnej ideologii „imitacyjnej modernizacji” i skupienia działalności rodzimych elit na celach narodowych, kształtowania poczucia lojalności opartej na tradycyjnej, polskiej tożsamości, propagowania nowych wzorców zachowań elit i zmian mechanizmów ich rekrutacji, wzmacniania normatywnej struktury społeczeństwa, gruntownej reformy prawa i dbałości o jego stosowanie (Z. Krasnodębski, Postkomunistyczna etyka i duch kapitalizmu, w: System wartości i norm społecznych podstawa rozwoju Polski, Instytut Badań nad Gospodarką Rynkową, Gdańsk 2005, s. 22-26; D. Gawin, Tożsamość polska w perspektywie historycznej, w: System wartości i norm społecznych podstawa rozwoju Polski, Instytut Badań nad Gospodarką Rynkową, Gdańsk 2005, s. 34-35). Wysuwany jest postulat nowego „wielkiego projektu cywilizacyjnego” dla Polski (M.A. Cichocki, Czy Polskę stać na jeszcze jeden wielki projekt cywilizacyjny? w: System wartości i norm społecznych podstawą rozwoju Polski, Instytut Badań nad Gospodarką Rynkową, Gdańsk 2005, s. 146-148), którego konkretyzację próbują wypracować m.in. Kongresy Polska. Wielki Projekt organizowane przez Instytut Sobieskiego od $2011 \mathrm{r}$.

${ }^{23} \mathrm{~W}$ sprawie oceny wariantu „polskiej drogi do modernizacji” politycznie utożsamianej z programem IV RP zob. Demokracja w Polsce 2005-2007, red. L. Kolarska-Bobińska, J. Kucharczyk, J. Zbieranek, Instytut Spraw Publicznych, Warszawa 2007; P. Szałamacha, IV Rzeczpospolita pierwsza odsłona. Dlaczego się nie udało, co trzeba zrobić, Zysk i S-ka, Poznań 2009. 
rządu Viktora Orbana na Węgrzech, który przez pewien czas dla liderów prawicy stanowił wzór do naśladowania lub ważny punkt odniesienia.

Podejście do strategii modernizacji stanowi od wielu lat jedną z głównych osi podziałów politycznych w Polsce. Zwolennicy konkurencyjnych koncepcji odmiennie rozkładają akcenty w ocenie zakresu i form obecności zewnętrznych aktorów w gospodarce. Jednak kluczowe ośrodki władzy państwowej i największe partie polityczne z rozmaitych przyczyn w tym zakresie często zmieniają stanowiska lub posługują się deklarowanymi koncepcjami bardzo instrumentalnie i nie nadają im charakteru całościowego ${ }^{24}$. Rządy sprawujące władzę od jesieni 2007 r. podejmują działania na rzecz odejścia od ograniczeń „imitacyjnej modernizacji” (np. poprzez próby realizacji własnej polityki energetycznej, wzmacnianie krajowych źródeł finansowania gospodarki czy konsolidację niektórych branż), lecz są one raczej ułomne i cząstkowe w sferze realizacji. Zapowiedzi rządzących polityków w ograniczonym zakresie przekładają się też na realne zmiany modernizacyjne. Świadczy o tym m.in. nadal stosunkowo niska konkurencyjność i innowacyjność polskich przedsiębiorstw, wolne tempo i kontrowersyjna jakość inwestycji infrastrukturalnych w drogownictwie i kolejnictwie czy niewielkie postępy w zakresie cyfryzacji państwa.

$\mathrm{W}$ znacznej mierze takie tendencje są następstwem kontynuowania przez polskie elity władzy po 1989 r. paradygmatu modernizacji imitacyjnej ${ }^{25}$. Strategia ta wytworzyła trudną do przełamania ścieżkę zależności, w ramach której projektowanie i wdrażanie nowych instytucji rozpatrywano głównie jako transfer lub adaptację istniejących już rozwiązań zachodnich do warunków polskich, a docelowym modelem przemian stało się „wysoko rozwinięte społeczeństwo rynkowe”26.

W takim kontekście w dyskusji na temat rozwoju Polski zwraca się często uwagę, że wyraźne zmniejszenie dystansu dzielącego nasze państwo od Europy Zachodniej dokonało się w gospodarce głównie za sprawą kapitału zagranicznego, co utrwaliło wzorzec „dyfuzji naśladowczej”, opartej na imporcie technologii i wykorzystaniu stosunkowo prostych rezerw w zakresie zarządzania, marketingu, tworzenia nowych powiązań biznesowych itd. Jak pokazują wyniki badań, wzorzec ten w rosnącym zakresie ujawnia jednak ograniczenia, których symptomem jest m.in. słabość krajowego

${ }^{24}$ Przykładów takich zjawisk dostarczają badania postaw elit politycznych wobec integracji Polski z UE. Złożony charakter postaw w tym zakresie obrazuje m.in. wielość rodzajów eurosceptycyzmu - ideologiczny, lobbystyczny bądź zasad oraz okoliczności, którym się posługują w niektórych okresach wszystkie partie polityczne (K. Jasiecki, Od euroentuzjazmu do eurosceptycyzmu?, w: Transformacja Elity Społeczeństwo, red. M. Jarosz, Instytut Studiów Politycznych PAN, Warszawa 2007, s. 65-94).

${ }_{25}$ M.S. Szczepański, Pokusy nowoczesności. Polskie dylematy rozwojowe, Amp, Kraków - Katowice 1992; C. Offe, Designing Institutions in East European Transitions, w: The Theory of Insitutional Design, red. R.E. Goodwin, G.H. Brennan, Cambridge University Press, Cambridge 1996, s. 199-226; Sustainable Democracy, red. A. Przeworski, Cambridge University Press, Cambridge 1995.

${ }^{26}$ H. Domański, Społeczeństwo europejskie..., op.cit., s. 9. 
zaplecza innowacyjności, nadmierne uzależnienie finansowania rozwoju od kapitału zagranicznego czy struktura handlu zagranicznego oparta na montowaniu i wytwarzaniu wyrobów średniej techniki, „wymyślonych” w innych państwach.

W elitach władzy świadomość tych ograniczeń znalazła odzwierciedlenie w raporcie przygotowanym przez zespół doradców premiera Donalda Tuska Polska 2030. Wyzwania rozwojowe. Zwracał on uwagę, że wstrzymywanie reform w różnych sferach gospodarki i społeczeństwa tworzy niebezpieczeństwo kumulowania się zagrożeń (instytucjonalnych, gospodarczych, demograficznych itd.), mogących w dłuższym czasie prowadzić do dryfu rozwojowego, rozumianego jako wygaszanie tempa modernizacji podjętej wraz z transformacją posocjalistyczną i akcesją do UE. Dla uniknięcia takiego scenariusza raport formułował postulat wyboru nowego modelu rozwojowego Polski, który miał mieć charakter innowacyjno-inwestycyjny, wykorzystujący możliwości unowocześniania struktury tworzenia PKB dzięki zwiększaniu inwestycji publicznych oraz funduszom europejskim. Dokument zawierał również zapowiedzi radykalnej przebudowy polityki państwa, w tym opracowania i realizacji długookresowego, strategicznego podejścia do rozwoju.

W zakresie wdrażania wysoko produktywnych technologii wskazywał na konieczność zwiększenia nakładów na infrastrukturę publiczną komplementarną wobec kapitału prywatnego (transportową, telekomunikacyjną, przesyłu energii), podatkowego preferowania inwestycji i oszczędności względem konsumpcji, a także zmian instytucjonalnych oraz regulacyjnych podnoszących jakość interwencji sektora publicznego ${ }^{27}$. Jednak raporty zespołu M. Boniego (ostatni z 2012 r.) nie uzyskały statusu dokumentów rządowych, nie były przyjmowane jako obowiązujące i nie prowadziły do działań operacyjnych. Przykład losów tych raportów, podobnie jak brak ośrodków programowania kierunków rozwoju Polski powoduje, że od dłuższego czasu formułowane są poglądy charakteryzujące słabość suwerennej myśli strategicznej w zakresie polityki gospodarczej Polski, wchodzenia państwa w fazę „dryfu rozwojowego" i niebezpieczeństwa „pułapki średniego dochodu”, zwłaszcza po wyczerpaniu napływu dużych środków inwestycyjnych z UE po roku $2020^{28}$.

${ }_{27}$ Polska 2030. Wyzwania rozwojowe, red. M. Boni, Kancelaria Prezesa Rady Ministrów, Warszawa 2009, s. 43-44.

${ }^{28}$ Kurs na innowacje. Jak wyprowadzić Polskę z rozwojowego dryfu?, red. J. Hausner, Fundacja Gospodarki i Administracji Publicznej, Kraków 2012; M. Bukowski, A. Szpor, A. Śniegocki, Potencjał i bariery polskiej innowacyjności, Instytut Badań Strukturalnych, Warszawa 2012. 


\section{Kapitalizm transnarodowy}

Część badaczy zwraca uwagę, że w drugiej połowie lat 90. w Polsce i innych państwach regionu zaczął się wyłaniać wariant kapitalizmu transnarodowego, którego zasadniczym wyróżnikiem stało się szybkie przejęcie kontroli przez zagraniczne korporacje nad usługami finansowymi, sektorami eksportowymi i handlem. Stały się one nowym, bardzo znaczącym aktorem gospodarki, zdolnym do przejmowania największych przedsiębiorstw oraz kontroli szczególnie rentownych sektorów biznesu. Sprzyjał im chroniczny deficyt krajowego kapitału inwestycyjnego, liberalizacja gospodarki, konieczność jej restrukturyzacji i warunki akcesji do UE. W takich okolicznościach inwestorzy zagraniczni i korporacje ponadnarodowe weszli w rolę głównego czynnika kształtującego profile przemysłowe oraz wybory polityki gospodarczej większości państw posocjalistycznych ${ }^{29}$.

W Polsce w 1994 r. przedsiębiorstwa z udziałem inwestorów zagranicznych dysponowały $8,9 \%$ majątku trwałego, $14 \%$ majątku obrotowego i zatrudniały $7 \%$ ogółu pracujących ${ }^{30}$. Po kilkunastu latach udział takich przedsiębiorstw w potencjale i aktywności gospodarczej ogółu firm ustabilizował się na poziomie 39-40\%. Kapitał zagraniczny kontrolował już 65\% całkowitego eksportu z Polski i zatrudniał ogółem $28,6 \%$ pracujących, w tym $43,3 \% \mathrm{w}$ pośrednictwie finansowym, $42,3 \% \mathrm{w}$ hotelach i restauracjach, 39,6\% w przetwórstwie przemysłowym, 34,2\% w przemyśle, 32,2\% w handlu i naprawach; $21,1 \% \mathrm{w}$ transporcie, gospodarce magazynowej i łączności, a 20,4\% w edukacji ${ }^{31}$. Firmy te dysponowały ponad połową ogółu aktywów trwałych w pośrednictwie finansowym $(65,7 \%), \mathrm{w}$ transporcie, gospodarce magazynowej i łączności (52,6\%), w przetwórstwie przemysłowym (51,8\%) oraz niemal połową

${ }^{29}$ L.P. King, I. Szelenyi, op.cit.; D. Bohle, B. Greskovits, Capitalist Diversity on Europe's Periphery, Cornell University Press, Cornell 2012; J. Drahokoupil, op.cit.; D. Lane, M. Myant, Varieties of Capitalism in Post-Communist Countries, Palgrave Macmillan, New York 2007; A. Nolke, A. Vliegenthart, Enlarging The Varieties of Capitalism: The Emergence of Dependent Market Economies in East Central Europe, "World Politics" 2009, no. 4, s. 670-702.

${ }^{30}$ Kapitał zagraniczny w prywatyzacji, red. M. Jarosz, Instytut Studiów Politycznych PAN, Warszawa 1996, s. 331.

${ }^{31}$ Dane GUS z grudnia 2008 r., opracowane na podstawie rocznych sprawozdań przedsiębiorstw zatrudniających 10 i więcej osób, wśród których wyróżnia się podmioty deklarujące posiadanie kapitału zagranicznego, niezależnie od stopnia zaangażowania tego kapitału (Inwestycje zagraniczne w Polsce, red. J. Chojna, Instytut Badań Rynku, Konsumpcji i Koniunktur, Warszawa 2010). Zob. także J. Różański, Przedsiębiorstwa zagraniczne w Polsce. Rozwój. Finansowanie. Ocena, Polskie Wydawnictwo Ekonomiczne, Warszawa 2010; M. Weresa, Wybrane aspekty innowacyjności polskiej gospodarki w warunkach globalizacji, w: Raport o innowacyjności gospodarki Polski w 2009 roku, red. T. Baczko, Instytut Nauk Ekonomicznych PAN, Warszawa 2010; M. Gorynia, Strategie firm polskich wobec ekspansji inwestorów zagranicznych, Państwowe Wydawnictwo Ekonomiczne, Warszawa 2005; A. Zorska, Ku globalizacji? Przemiany w korporacjach transnarodowych i w gospodarce światowej, Wydawnictwo Naukowe PWN, Warszawa 2002. 
w handlu i naprawach $(48,9 \%)^{32}$. W wymiarze mikroekonomicznym dynamikę i gospodarczą rolę kapitału zagranicznego obrazowo oddaje ranking 500 największych przedsiębiorstw działających w Polsce publikowany przez „Rzeczpospolitą”. Zgodnie z jego edycją z 2014 r., w „wielkim biznesie” głównymi aktorami są inwestorzy zagraniczni i firmy państwowe. Chociaż na liście największych przedsiębiorstw znajdują się 202 rodzime firmy prywatne, to ich łączny udział w przychodach firm $\mathrm{z}$ rankingu wynosi tylko 19\%. Dla porównania: 258 firm z kapitałem zagranicznym uzyskuje 53\% przychodów, a 34 przedsiębiorstwa państwowe mają w nich 28-procentowy udział ${ }^{33}$. W zestawieniu z firmami inwestorów zagranicznych, a także spółkami skarbu państwa, dane dotyczące rodzimych przedsiębiorstw prywatnych są wskaźnikiem słabości akumulacji polskiego biznesu, jego dużego rozproszenia i wczesnej fazy konsolidacji ${ }^{34}$.

W strukturze polskiej gospodarki dominują bowiem mikroprzedsiębiorstwa zatrudniające mniej niż 10 pracowników, które stanowią blisko 96\% ogółu firm prywatnych, w tym około 15\% samozatrudnionych. Udział firm małych (10-49 pracowników) wynosi tylko nieco ponad 3\%, a średnie firmy (50-249) stanowią niespełna $1 \%$. Jest ich dwukrotnie mniej niż przeciętnie w UE. Taka rozdrobniona struktura firm tworzy modele biznesowe niekorzystnie wpływające na międzynarodową konkurencyjność Polski oraz jest przejawem ekonomicznej słabości rodzimego kapitału i rynkowych klas średnich ${ }^{35}$.

Kluczowym wymiarem tego zjawiska jest pośrednictwo finansowe. W warunkach globalizacji i finansjalizacji podporządkowującej gospodarkę, jak również inne obszary życia społecznego, racjonalności rynków kapitałowych, zasadniczą rolę pełni sektor

32 Już w styczniu 1990 r. w opinii zespołu doradców socjologicznych Obywatelskiego Klubu Parlamentarnego (OKP) znalazł się zapis: „Nasza gospodarka jest prawdopodobnie zbyt słaba na całkowitą liberalną konfrontację z rynkiem światowym. Konieczne jest zatem pilne zbadanie, czy zasady prywatyzacji nie stwarzają groźby uszczuplenia bądź nawet utraty suwerenności gospodarczej Polski. Naszej gospodarki nie może bronić rodzimy kapitał, bo go praktycznie nie ma, więc obowiązek ten - przynajmniej w pierwszej fazie rekonstrukcji - musi przejąć na siebie państwo" (E. Wnuk-Lipiński, Opinia w sprawie prywatyzacji gospodarki narodowej, w: Z archiwów OKP. Ekspertyzy zespołu doradców socjologicznych Obywatelskiego Klubu Parlamentarnego, Wydawnictwo Naukowe PWN, Warszawa 1989-1990, s. 39).

${ }^{33}$ Lista 500 największych przedsiębiorstw działających w Polsce, „Rzeczpospolita” 23.04.2014, s. 24-26.

${ }^{34}$ Wśród autorów rankingów największych przedsiębiorstw działających w Polsce od lat dyskutowane jest prawdopodobieństwo większego udziału inwestorów zagranicznych w polskiej gospodarce niż wynika to ze sprawozdawczości. Zarówno firmy kontrolowane przez zagranicznych inwestorów, jak i przedsiębiorstwa krajowe (z wyjątkiem spółek giełdowych) często traktują jawność danych wybiórczo, w sposób, który jest dla nich wygodny. Niska rentowność wykazywana przez spółki z udziałem kapitału zagranicznego w sprawozdaniach bilansowych jest tym bardziej zastanawiająca, że charakteryzuje je zwykle wyższa wydajność pracy, bardziej nowoczesny potencjał produkcyjny, większy udział eksportu, efektywne zarządzanie i organizacja. W wypadku korporacji transnarodowych istnieją jednak duże możliwości wyprowadzania zysków za pomocą cen transferowych, płatności dywidend, opłat za usługi menedżerskie i opłaty licencyjne, wystawiania faktur w różnych walutach, tworzenia centrów refakturujących itd.

${ }_{35}$ Rzemieślnicy i biznesmeni. Właściciele małych i średnich przedsiębiorstw, red. J. Gardawski, Wydawnictwo Naukowe Scholar, Warszawa 2013. 
bankowy. Warto odnotować, że jeszcze w końcu 1993 r. banki z przewagą kapitału zagranicznego stanowiły w strukturze własnościowej sektora bankowego w Polsce $12 \%$, w 1995 roku - 22\%, w 1996 roku - 31\%, w 1999 roku - 51\%, a w 2003 roku już 78\% ${ }^{36}$. Później udział inwestorów zagranicznych w sektorze bankowym zaczął stopniowo się zmniejszać, a po przejęciu przez największy rodzimy bank PKO BP od właścicieli skandynawskich Nordea Bank łącznie wynosi on nieco mniej niż $60 \%$ aktywów sektora.

Tabela 1 pokazuje, że podobne zależności w strukturze własności 500 największych przedsiębiorstw występują w gospodarce większości państw Europy Środkowej i Wschodniej. Niektóre, jak Macedonia, Węgry, Rumunia lub Słowacja są zdominowane przez kapitał zagraniczny i nie mają własnych znaczących firm prywatnych. W innych kapitał państwowy oraz krajowy prywatny stanowi stosunkowo niedużą część największych firm. Warto jednak odnotować, że w skali całego regionu udział spółek kontrolowanych przez inwestorów zagranicznych w przychodach największych przedsiębiorstw spada systematycznie od trzech lat. W 2011 r. przekraczał on 57\%, a obecnie wynosi $53 \%{ }^{37}$.

Tabela 1. Struktura własności 500 największych przedsiębiorstw w wybranych państwach Europy Środkowej i Wschodniej

\begin{tabular}{|l|c|c|c|}
\hline \multicolumn{4}{|c|}{ Spółki kontrolowane przez kapitał (w proc.) } \\
\hline Macedonia & Zagraniczny & Prywatny krajowy & Państwowy \\
\hline Węgry & 100,0 & 0,0 & 0,0 \\
\hline Rumunia & 87,3 & 1,6 & 11,1 \\
\hline Stowacja & 80,5 & 7,3 & 12,2 \\
\hline Bośnia i Hercegowina & 75,0 & 0,0 & 25,0 \\
\hline Czechy & 66,7 & 0,0 & 33,3 \\
\hline Serbia & 65,8 & 16,5 & 17,0 \\
\hline Bułgaria & 60,0 & 10,0 & 30,0 \\
\hline Polska & 57,1 & 28,0 & 14,3 \\
\hline Estonia & 56,8 & 19,0 & 23,5 \\
\hline Litwa & 40,0 & 40,0 & 20,0 \\
\hline Ukraina & 38,5 & 46,0 & 15,4 \\
\hline Chorwacja & 34,0 & 52,0 & 13,2 \\
\hline Stowenia & 33,3 & 33,0 & 33,3 \\
\hline Ogótem & 33,3 & 50,0 & 18,8 \\
\hline
\end{tabular}

Źródło: Deloitte CE TOP 500 ranking, ,Rzeczpospolita”, 03.09.2014.

36 A. Szelągowska, Kapitat zagraniczny w polskich bankach, Poltext, Warszawa 2004.

${ }^{37}$ Europa 500 największych firm Europy Srodkowo-Wschodniej, „Rzeczpospolita”, 03.09.2014, s. 18. 


\section{Neoliberalne podejście do kapitału zagranicznego i jego ograniczenia}

Zmiany ustrojowe w Polsce od początku opierały się głównie na neoliberalnej teorii modernizacji przyjmującej, że pochodzenie kapitału nie ma istotnego znaczenia, a „kapitał nie ma narodowości”. W takiej perspektywie inwestorzy zagraniczni traktowani są jednoznacznie pozytywnie jako katalizator i jeden z wiodących aktorów reform przyspieszających przekształcenia strukturalne, dostarczając niezbędnych zasobów gospodarczych. Tworzą także kluczowe instytucjonalne powiązania z państwami wysoko rozwiniętymi (zwłaszcza z Europą Zachodnią), niezbędne w przezwyciężaniu posocjalistycznego dziedzictwa przeszłości w sferze przedsiębiorczości i zarządzania, dostępu do kapitału i nowoczesnych technologii.

Inwestorzy zagraniczni wypadają szczególnie pozytywnie na tle niskiej efektywności rodzimego sektora publicznego, w którym dostosowania modernizacyjne są znacznie wolniejsze. W wymiarze kulturowym wprowadzają nowe wzory zachowań związane ze standardami nadzoru korporacyjnego i społecznej odpowiedzialności biznesu (CSR), które modernizują także inne obszary życia społecznego, w tym prawo, edukację, stosunki pracy oraz instytucje otoczenia gospodarczego. Ich dynamizm, propagowane style życia i wzory konsumpcji stanowią istotny czynnik kształtowania się nowych klas średnich i elit, które stają się rdzeniem nowej „klasy wyższej”38.

Jednak sposób przejmowania rynku i efekty dominującej pozycji inwestorów zagranicznych w wielu wymiarach odbiegają od ideologicznych oczekiwań reformatorów. Mają także wiele negatywnych konsekwencji. Gwałtowny wzrost penetracji zagranicznych inwestorów w polskiej gospodarce ogranicza możliwości prowadzenia polityki gospodarczej przez władze państwowe oraz działania rodzimego kapitału, utrwala słabość klas średnich i elity krajowego biznesu. Część badaczy wskazuje, że nowa struktura gospodarcza staje się ważnym wskaźnikiem gospodarczej „peryferyjności” Polski na tle państw Europy Zachodniej. Potwierdza również prognozy, że liberalizacja handlu z Zachodem i otwarcie na swobodne przepływy kapitału wyznaczają Polsce rolę źródła relatywnie niskopłatnej kadry średniego szczebla i podwykonawców międzynarodowych korporacji, które podporządkowują rozwój swoich lokalnych oddziałów preferencjom kapitału z państw wysoko rozwiniętych ${ }^{39}$.

${ }^{38}$ K. Jasiecki, Elita biznesu w Polsce. Drugie narodziny kapitalizmu, Instytut Filozofii i Socjologii PAN, Warszawa 2002.

${ }^{39}$ H.A. Amsden, J. Kochanowicz, L. Taylor, The Market Meets Its Match. Restructuring the Economies of Eastern Europe, Harvard University Press, Cambridge 1994; T.I. Berend, Central and Eastern Europe 
Widoczne jest kształtowanie się systemu gospodarczego opartego na dominacji międzynarodowych korporacji współistniejących z dużym sektorem państwowym i słabym krajowym sektorem prywatnym. Takie proporcje przenoszone są również do innych obszarów życia społecznego. Ich przejawem jest m.in. polityka zagospodarowania przestrzennego, przekształcenia przestrzeni zurbanizowanych, przyspieszanie deindustrializacji i reindustrializacja, której cele i formy wyznacza kapitał zagraniczny, ekspansja biurowców, promowanie nowych form konsumpcji oraz rekreacji, budowa centrów handlowych, sieci sklepów wielkopowierzchniowych czy osiedli mieszkaniowych tworzących popyt na import towarów i usług ${ }^{40}$.

Ideologicznym wyrazem nowych zależności są konflikty pomiędzy identyfikującymi się z kulturowymi centrami Zachodu środowiskami lewicowymi i liberalnymi oraz orientacją narodowo-konserwatywną, odwołującą się do polskich tradycji i katolicyzmu przeciwstawianych postawom konsumpcyjnym i laicyzacji ${ }^{41}$. Powyższe tendencje stały się przedmiotem dyskusji akcentujących, że transformacja posocjalistyczna oprócz tendencji modernizacyjnych wytwarza także różne „nowe” formy zależności politycznych, gospodarczych i kulturowych od państw wyżej rozwiniętych, w wypadku Polski głównie od państw zachodnich ${ }^{42}$.

$\mathrm{W}$ rezultacie stało się dyskusyjne, czy polska gospodarka będzie w stanie utrwalić pozytywne tendencje związane z próbą „ucieczki z peryferii”. W Polsce nie powstały wielkie korporacje, które byłyby - jak niegdyś Nokia w Finlandii - rodzimym odpowiednikiem instytucji podmiotowego wchodzenia w międzynarodowy podział pracy. Trudno zakładać, że czynnikiem dynamizującym rozwój państwa będą mikroprzedsiębiorstwa lub na ogół mało efektywne firmy państwowe, zarządzane przez często wymienianych menedżerów, pochodzących z nominacji partyjnych. Taka sytuacja znalazła odzwierciedlenie w klasyfikacjach uznających Polskę i Europę Środkową za nowy wariant neoliberalnej „zależnej gospodarki rynkowej”43, regionalnego kapitalizmu transnarodowego ${ }^{44}$, kapitalizmu $\mathrm{z}$ wiodącą rolą kapitału zagranicznego ${ }^{45}$ bądź liberalnego kapitalizmu „Z zewnątrz"46.

1944-1993. Detour from the Periphery to the Periphery, Cambridge University Press, Cambridge 1996; J. Kochanowicz, op.cit.; A. Sosnowska, op.cit.

${ }^{40}$ B. Jałowiecki, Społeczne wytwarzanie przestrzeni, Wydawnictwo Naukowe Scholar, Warszawa 2010; K. Jasiecki, Korzyści i koszty działania hipermarketów, „Prakseologia” 2007, nr 147, s. 115-146.

${ }^{41}$ T. Zarycki, op. cit.

${ }^{42}$ M.S. Szczepański, Ani Elizjum, ani Hades..., op.cit.; Z. Krasnodębski, Demokracja peryferii, słowo/obraz terytoria, Gdańsk 2003.

${ }^{43}$ A. Nolke, A. Vliegenthart, op.cit.

${ }_{44}$ D. Bohle, B. Greskovits, Neoliberalizm, Embedded Neoliberalism and Neocorporatism: Towards Transnational Capitalism in Central-Eastern Europe, "West European Politics" 2007, vol. 30, no. 3, s. 443-466.

${ }^{45}$ L.P. King, op.cit.

${ }^{46}$ L.P. King, I. Szelenyi, op.cit. 


\section{Pastwisko globalnych graczy?}

Od końca lat 90. w niektórych instytucjach rządowych (zwłaszcza wśród orędowników liberalno-konserwatywnej koncepcji modernizacji), zaczęto dostrzegać, że dotychczasowy przebieg zmian systemowych oprócz reform i unowocześnienia państwa zaczyna także w wielu aspektach w nowy sposób reprodukować słabość polskiej przedsiębiorczości i generuje nadmierne uzależnienie od inwestycji zagranicznych. Raport Rządowego Centrum Studiów Strategicznych w 1998 r. sformułował obawy dotyczące możliwości przekształcenia Polski w zaplecze surowcowe i rezerwę taniej siły roboczej rozwiniętych państw UE. W dyskusji o ograniczeniach polityki gospodarczej prezes Instytutu Badań nad Gospodarką Rynkową stosunek instytucji publicznych do rodzimej przedsiębiorczości nazwał „strategią pastwiska dla globalnych korporacji”, która grozi skazaniem państwa na trwałą peryferyjność, a Polaków na rolę wiecznych pracobiorców w tych korporacjach ${ }^{47}$.

W kontekście trajektorii wychodzenia $\mathrm{z}$ komunizmu w warunkach globalizacji, J. Staniszkis sformułowała tezę o „niekompletnym kapitalizmie”, marginalizującym w nowy sposób Polskę w relacjach z centrami współczesnego świata. Tezę tę uzasadnia słabość mechanizmów akumulacji krajowego kapitału wynikająca z blokowania wewnętrznych źródeł rozwoju poprzez integrację ze strukturami unijnymi, które podporządkowują gospodarkę Polski racjonalności globalnego kapitalizmu. Polska, podobnie jak inne państwa pokomunistyczne poddane "przemocy strukturalnej”, realizuje reformy spełniające oczekiwania organizacji międzynarodowych. Przekształciły one instytucje państwa w struktury pracujące na rzecz układu szerszego i o innych celach niż krajowe lub państwowe. Integracja z OECD, a później UE, stała się przejawem poddania się asymetrycznej racjonalności odzwierciedlającej logikę globalnej władzy nad pokomunistycznymi półperyferiami ${ }^{48}$.

W takiej interpretacji, w końcu lat 90., w Polsce zaczął wyczerpywać się potencjał wzrostu, zużywający rezerwy z okresu PRL uruchomione dzięki uwolnieniu rynku, przekształceniom własnościowym, wprowadzeniu nowych form zarządzania i wykorzystaniu kumulowanego przez lata popytu konsumpcyjnego. Pojawiły się natomiast wewnętrzne bariery rozwoju, spowodowane m.in. niesprawnością instytucji państwa, przedwczesną dezindustrializacją i słabością kapitałową rodzimego biznesu. Na poziomie makroekonomicznym następuje przerwanie cyklu kapitalistycznej reprodukcji

${ }^{47}$ J. Szomburg, Atrakcyjna Polska, czyli jaka?, „Rzeczpospolita”, 01.03.2007.

48 J. Staniszkis, Postkomunizm. Próba opisu, słowo/obraz terytoria, Gdańsk 2001; J. Staniszkis, Władza globalizacji, Wydawnictwo Naukowe Scholar, Warszawa 2003. 
z fazą inwestycji i rozszerzonej reprodukcji spowodowane tym, że instytucje finansowe chętniej obsługiwały dług publiczny niż kredytowały inwestycje. Na poziomie mikro odpisy amortyzacyjne nie pokrywają kosztów odtworzenia majątku, a niska stopa inwestycji wraz ze słabością kultury kontraktu skraca perspektywę czasu transakcji, co sprzyja preferowaniu szybkich zysków kosztem lojalności wobec klientów i współpracowników.

W takim wariancie gospodarki procedury, instytucje i sprzężenia między nimi pracują na rzecz całości o skali większej niż ów system - unijnej lub globalnej. Mechanizmy "niekompletnego kapitalizmu” są następstwem błędnych decyzji dotyczących wyboru instytucji, podjętych na początku transformacji, które w znacznej mierze zostały narzucone z zewnątrz - wraz z logiką „konsensu waszyngtońskiego”. Mają one charakter racjonalny dla stadium kapitalizmu rozwiniętego i skali operacji korporacji transnarodowych.

Główny problem większości europejskich państw posocjalistycznych polega na słabości mechanizmów zapewniających wewnętrzną akumulację kapitału, która umożliwiałaby rozwój gospodarczy bez znacznego zasilania inwestycyjnego z zewnątrz, np. funduszami z UE i kapitałem zagranicznym. Ceną za połowiczne wejście Polski w struktury unijne i globalne jest również mała sterowność państwa rozumiana jako brak zdolności do osiągania założonych celów, a także niewielka zdolność do autonomicznego i podmiotowego rozwoju ekonomicznego. Jednak badania empiryczne działalności inwestorów zagranicznych w Polsce skłaniają do bardziej zróżnicowanych ocen ich wpływu na gospodarkę. Rola ta zmieniała się w kolejnych fazach rozwoju gospodarczego, gdy możliwe stawało się porównanie efektów działalności różnych rodzajów przedsiębiorstw w dłuższym okresie.

\section{Bilans zysków i strat}

Generalnie, wyniki badań nie potwierdzają nadmiernie optymistycznych nadziei, jakie wiązali neoliberalni reformatorzy z wejściem inwestorów zagranicznych do Polski, ale kwestionują one również (chociaż w mniejszym zakresie) oceny dostrzegające w kapitale zagranicznym jedynie narzędzie utrwalania „peryferyjności” polskiej gospodarki. Przewaga efektów pozytywnych lub efektów negatywnych zależy głównie od sytuacji w sferach gospodarczej, społecznej i politycznej w państwie goszczącym, a także od rozwiązań przyjętych przez inwestora zagranicznego ${ }^{49}$. Bilans

49 J. Różański, op.cit., s. 95. 
zysków i strat związanych z bezpośrednimi inwestycjami zagranicznymi jest złożony i wielowymiarowy.

Niektóre z korzyści nie budzą większych kontrowersji, jak nowe wzorce zarządzania, napływ nowoczesnych technologii lub kapitału inwestycyjnego. Inne bywają problematyczne, prowadzą bowiem do istotnych niedogodności, np. dodatkowe wpływy z podatków związane z działalnością inwestorów zagranicznych mogą być znacząco uszczuplone przez transfer zysków za granicę. Dyskusyjne są też kwestie często trudno mierzalne, jak przepływy pieniężne napływające (inward) oraz odpływające (outward) za sprawą inwestorów zagranicznych. Z kolei relacje między przedsiębiorstwami lokalnymi a inwestorami zagranicznymi są bardzo różnorodne i nie ograniczają się do kategorii gry o sumie zerowej. Wielowymiarową analizę różnych kategorii pozytywnych i negatywnych efektów zewnętrznych bezpośrednich inwestycji zagranicznych prezentuje tabela 2.

Firmy zagraniczne wchodzące na polski rynek stają się także firmami polskimi, działają według norm prawa polskiego, zatrudniają polskich pracowników, płacą podatki, są nie tylko konkurentami, lecz również kooperantami, dostawcami i odbiorcami usług lokalnych przedsiębiorstw. Ich relacje z miejscowymi firmami częściowo zmieniają swój charakter ${ }^{50}$. W tym zakresie znaczące są uwagi A. Zorskiej, która podkreśla szczególnie pozytywny wpływ inwestorów zagranicznych w początkowej fazie transformowania gospodarki, tworzenia konkurencyjnego rynku i umiędzynarodowienia działalności gospodarczej.

W debacie publicznej w Polsce dominują poglądy zdecydowanie pozytywne wobec inwestycji zagranicznych, natomiast inaczej jest w środowiskach akademickich (a także w części politycznych). Pojawiło się przeświadczenie, że bilans korzyści i kosztów związanych z ich ekspansją staje się dyskusyjny, zwłaszcza na tle słabości mechanizmów akumulacji kapitału krajowego i ograniczonych możliwości rozwojowych rodzimych przedsiębiorstw tracących udziały w rynkach kontrolowanych przez firmy zagraniczne. „Po 10-ciu latach okazało się, że zaangażowanie w przemiany sprzyjało interesom głównie samych korporacji, które stały się najsilniejszymi konkurentami na polskim rynku. Świadczy o tym bardzo wysoki niekiedy stopień penetracji krajowego rynku przez KMN, prowadzący nawet do jego oligopolizacji w niektórych dziedzinach" ${ }^{51}$.

${ }^{50} \mathrm{~W}$ kwestii strategii polskich firm wobec inwestorów zagranicznych zob. m.in. M. Gorynia, op.cit; Polskie grupy kapitałowe. Perspektywa Europejska, red. B. Wawrzyniak, Wydawnictwo Wyższej Szkoły Przedsiębiorczości i Zarządzania im. Leona Koźmińskiego, Warszawa 2002.

${ }^{51}$ A. Zorska, op.cit., s. 74. 
Tabela 2. Pozytywne i negatywne efekty zewnętrzne bezpośrednich inwestycji zagranicznych dla państwa przyjmującego

\begin{tabular}{|c|c|c|}
\hline Kategoria efektów & Pozytywne & Negatywne \\
\hline Polityczne & $\begin{array}{l}\text { presja na przejrzystość, stabilność i jakość } \\
\text { infrastruktury prawnej, informacyjnej, } \\
\text { komunikacyjnej i finansowej }\end{array}$ & $\begin{array}{l}\text { możliwość wywierania wpływu na decyzje } \\
\text { polityczne w kraju goszczącym w celu } \\
\text { wymuszenia korzystnych dla inwestora } \\
\text { regulacji }\end{array}$ \\
\hline Ogólnogospodarcze & $\begin{array}{l}\text { wypełnienie luki między pożądanym poziomem } \\
\text { inwestycji a oszczędnościami krajowymi, } \\
\text { umocnienie krajowej waluty, } \\
\text { zwiększenie wpływów budżetowych, } \\
\text { wzrost zatrudnienia i wydajności pracy, } \\
\text { poprawa wizerunku kraju i jego pozycji } \\
\text { w rankingach międzynarodowych }\end{array}$ & $\begin{array}{l}\text { zmniejszenie stopy oszczędności krajowych, } \\
\text { osłabienie motywacji do powiększania } \\
\text { krajowych oszczędności, } \\
\text { ograniczenie suwerenności i skuteczności } \\
\text { krajowej polityki makroekonomicznej, } \\
\text { napływ kapitału spekulacyjnego i pranie } \\
\text { brudnych pieniędzy, } \\
\text { redukcja zatrudnienia }\end{array}$ \\
\hline Społeczne & $\begin{array}{l}\text { umożliwienie finansowania wydatków } \\
\text { rządowych przez wpływy z podatków } \\
\text { płaconych przez inwestorów zagranicznych, } \\
\text { promocja pozytywnych wzorców kulturowych } \\
\text { i konsumpcyjnych }\end{array}$ & $\begin{array}{l}\text { faworyzowanie niewielu dobrze opłacanych, } \\
\text { zatrudnionych w nowoczesnym sektorze } \\
\text { pracowników, } \\
\text { wysokość podatków płaconych przez } \\
\text { inwestorów zagranicznych może być niższa od } \\
\text { przyznanych im świadczeń }\end{array}$ \\
\hline Obroty zagraniczne & $\begin{array}{l}\text { wypełnienie luki między potrzebami } \\
\text { importowymi a dochodami z eksportu, } \\
\text { poprawa salda obrotów bieżących, } \\
\text { poprawa terms of trade }\end{array}$ & $\begin{array}{l}\text { wzrost importu, } \\
\text { pogarszanie się salda bilansu handlowego } \\
\text { i płatniczego, } \\
\text { pogarszanie się terms of trade, zwłaszcza } \\
\text { jeśli firmy zagraniczne w niewielkim stopniu } \\
\text { korzystają z dostaw krajowych i dokonują } \\
\text { transferu znacznej części zysków } \\
\end{array}$ \\
\hline Nauka i technika & $\begin{array}{l}\text { rozwój sfery naukowo-badawczej, } \\
\text { transfer myśli naukowo-technicznej } \\
\text { i nowoczesnych technologii, } \\
\text { podnoszenie kwalifikacji kadr krajowych }\end{array}$ & $\begin{array}{l}\text { możliwość zastąpienia stanowisk pracy } \\
\text { wymagających wiedzy technicznej } \\
\text { stanowiskami wymagającymi jedynie pracy } \\
\text { ręcznej, } \\
\text { likwidowanie/redukowanie krajowego zaplecza } \\
\text { B+R, } \\
\text { transfer wysoko wykwalifikowanej kadry } \\
\text { krajowej do central firm zagranicznych, } \\
\text { ryzyko napływu „brudnych” i przestarzałych } \\
\text { technologii, } \\
\text { przywiązywanie niewielkiej wagi do szkolenia } \\
\text { kadr krajowych oraz rezerwowanie stanowisk } \\
\text { kierowniczych dla kadry z kraju pochodzenia } \\
\text { kapitału }\end{array}$ \\
\hline $\begin{array}{l}\text { Konkurencyjność } \\
\text { przedsiębiorstw }\end{array}$ & $\begin{array}{l}\text { dostarczanie pozytywnych i efektywnych } \\
\text { wzorców dotyczących przedsiębiorczości } \\
\text { i zarządzania, } \\
\text { zmuszenie lokalnych firm do większej } \\
\text { efektywności i innowacyjności, } \\
\text { ograniczenie roli monopoli krajowych } \\
\text { i negatywnych skutków ich funkcjonowania }\end{array}$ & $\begin{array}{l}\text { ryzyko nieuczciwej konkurencji w stosunku do } \\
\text { firm krajowych, } \\
\text { transfer zysków z przejętych firm lokalnych, } \\
\text { wypieranie z rynków zagranicznych krajowych } \\
\text { producentów, } \\
\text { absorpcja przez kapitał zagraniczny krajowych } \\
\text { zasobów kredytowych }\end{array}$ \\
\hline
\end{tabular}

Źródło: Strategie firm polskich wobec ekspansji inwestorów zagranicznych, red. M. Gorynia, PWE, Warszawa 2005, s. 74-75. 
Rozmaite negatywne tendencje w tym zakresie występują najbardziej wyraźnie w zakresie rozwoju nauki i techniki mierzonych niskimi wskaźnikami innowacyjności polskich przedsiębiorstw oraz niewielką grupą krajowych firm inwestujących w B+R. Tego rodzaju zjawiska znane są również w innych obszarach - wpływów politycznych, w postaci silnych lobbies i rozbudowanych praktyk korupcyjnych na rzecz inwestorów zagranicznych ${ }^{52}$, które osłabiają możliwości prowadzenia spójnej polityki gospodarczej państwa, ułatwiają przejmowanie przez kapitał zagraniczny najlepszych polskich przedsiębiorstw oraz wysoko rentownych branż gospodarki (usługi finansowe, telekomunikacja, przemysł eksportowy), a także ograniczania potencjału krajowego biznesu, m.in. za pomocą przenoszenia strategicznych działów i produktów za granicę lub likwidowania oddziałów polskich banków w innych państwach.

Wśród innych zbliżonych zjawisk wskazywana jest często niechęć inwestorów zagranicznych wobec kredytowania krajowego sektora MŚP, zrywanie kontraktów z lokalnymi kooperantami i przerywanie sieci rodzimych powiązań, nadużywanie silniejszej pozycji przetargowej w relacjach z polskim biznesem, rozwój firm z kapitałem zagranicznym kosztem lokalnych przedsiębiorstw, znaczące transfery zysków za granicę (tzw. efekt odkurzacza), wykorzystywanie relatywnie tanich pracowników dla wzmocnienia pozycji konkurencyjnej przedsiębiorstw transnarodowych czy nacisk na obniżanie standardów stosunków pracy, w tym rozrost prekariatu opierający się na lokalnym prawie stanowionym dla przyciągania inwestorów zagranicznych ${ }^{53}$.

W efekcie coraz częściej wyrażany jest pogląd, iż „strategia pastwiska dla globalnych korporacji” uzasadniana koniecznością szybkiego niwelowania dystansu do państw rozwiniętych w nowy sposób utrwala podrzędną pozycję Polski w międzynarodowym podziale pracy. „Długofalowo może to prowadzić do petryfikowania obecnych struktur i charakteru działalności gospodarczej w Polsce, a w konsekwencji do oddalenia się szans na awansowanie w tworzącej się "nowej « Europie i globalnej gospodarce" ${ }^{\text {" }}$.

Jak pokazuje tabela 2, negatywne aspekty działalności firm kontrolowanych przez kapitał zagraniczny mają (lub mogą mieć) na tyle duży ciężar gatunkowy, że przeciwdziałanie im wymaga podejmowania kompleksowych i aktywnych działań przez państwo, przedsiębiorstwa oraz innych aktorów gospodarki ${ }^{55}$. Bez tego nie da

52 Np. L. Oręziak, OFE. Katastrofa prywatyzacji emerytur w Polsce, Książka i Prasa, Warszawa 2014; P. Polak, Nowe formy korupcji. Analiza socjologiczna sektora farmaceutycznego w Polsce, Nomos, Kraków 2011.

53 Zjawisko prekariatu, jego przesłanki i strategie wprowadzania charakteryzuje G. Standing, Prekariat. Nowa niebezpieczna klasa, Wydawnictwo Naukowe PWN, Warszawa 2014.

54 A. Zorska, op.cit., s. 75; zob. także M. Gorynia, op.cit.; J. Różański, op.cit.

55 Badania empiryczne wykazały, że przekroczenie w początkowym okresie transformacji pewnego krytycznego progu penetracji importu w stosunku do produkcji krajowej w niektórych branżach, np. w przemyśle informatycznym lub wyrobów elektronicznych, doprowadziło do degradacji gałęzi technologicznie najbardziej zaawansowanych, decydujących o potencjale wzrostu gospodarczego Polski 
się zbudować potencjału, który mógłby, odwołując się do terminologii U. Becka, włączyć polskie przedsiębiorstwa i gospodarkę państwa do globalnej „gry w szachy”, bez poprzestawania na poziomie „gry w warcaby”, ograniczającej rolę polskich firm głównie do podwykonawstwa średnio konkurencyjnych i przeciętnie wynagradzanych zleceń transnarodowych korporacji.

\section{$* * *$}

Kryzys 2007+ stał się katalizatorem wielu zmian teoretycznych i praktycznych w podejściu do roli państwa, reguł rozwoju gospodarczego oraz własności kapitału, a także własności przedsiębiorstw. Do przeszłości należą poglądy, opierające się na niekrytycznym zaufaniu do spontanicznego przebiegu globalizacji i liberalizacji rynków, co łączyło się z naciskiem na pozyskanie inwestorów zagranicznych zdolnych do sprywatyzowania przedsiębiorstw oraz obniżenia kosztów transakcyjnych. Wielki kryzys wymusza redefiniowanie związków polityki i ekonomii, sprzyja wychodzeniu poza dominujące do niedawna standardy teoretyczne, zwraca uwagę na często przemilczane problemy oraz otwiera nowe perspektywy badawcze zarówno w kwestiach gospodarczych, jak również w innych obszarach nauk społecznych, podejmujących, jak filozofia, etyka i antropologia, refleksję nad kluczowymi wymiarami ludzkiej egzystencji ${ }^{56}$.

W takiej perspektywie ulegają istotnemu przewartościowaniu także poglądy dotyczące roli kapitału zagranicznego w zmianach gospodarczych i instytucjonalnych w Europie Środkowej i Wschodniej. Dynamiczny rozwój gospodarczy Polski po upadku socjalizmu państwowego stał się możliwy w znacznej mierze dzięki napływowi inwestycji zagranicznych. Orędownicy neoliberalnej polityki gospodarczej akcentują, że przyczynił się on zasadniczo do zwiększenia produkcji i ekspansji eksportowej na rynki unijne produktów wytwarzanych w Polsce. Rośnie systematycznie umiędzynarodowienie polskiej gospodarki (mierzone m.in. wskaźnikami eksportu do PKB), które zwiększa udział państwa w globalnych łańcuchach produkcji, co przyspiesza procesy modernizacyjne. Znaczne korzyści odniosły również firmy z krajowym kapitałem współpracujące z inwestorami zagranicznymi i korporacjami

(M. Perczyński, Międzynarodowe stosunki gospodarcze Polski w okresie otwierania się i transformacji gospodarki, w: Dynamika transformacji polskiej gospodarki, red. M. Belka, W. Trzeciakowski, Poltext, Warszawa 1997, s. 267-302).

56 Zob. A. Szahaj, Kapitalizm drobnego druku, Książka i Prasa, Warszawa 2014; T. Sedlacek, Ekonomia dobra i zła. W poszukiwaniu istoty ekonomii od Gilgamesza do Wall Street, tłum. D. Bakalarz, Studio EMKA, Warszawa 2012; D. Rodrik, The Globalization Paradox. Why Global Markets, States, and Democracy Can't Coexist, Oxford University Press, Oxford 2011; Ekonomia i polityka w kryzysie. Kierunki zmian w teoriach, red. M. Guzek, Uczelnia Łazarskiego - ISP PAN, Warszawa 2012; N. Roubini, S. Mihm, Ekonomia kryzysu, tłum. R. Mitoraj, Oficyna Wolters Kluwer, Warszawa 2011. 
transnarodowymi. Presja zagranicznych spółek wymusza m.in. unowocześnienie produkcji i wzrost wydajności pracy (do czego przyczyniło się również wejście na jednolity rynek europejski i napływ funduszy unijnych), odzwierciedlone we wzroście PKB oraz wynagrodzeń. Dzięki inwestycjom zagranicznym zredukowany został istotnie dystans cywilizacyjny i kulturowy Polski do standardów światowych w sferze wzorców racjonalności gospodarczej, jakości zarządzania firm, stylu życia oraz wzorów konsumpcji.

Od końca lat 90. narasta jednak krytyka roli inwestorów zagranicznych w Polsce. Tendencję tę wzmocnił globalny kryzys kapitalizmu 2007+ i jego następstwa w UE, czego najbardziej nośnym przejawem stały się postulaty „repolonizacji” banków komercyjnych, odgrywające rolę katalizatora analogicznych dyskusji również w innych sektorach gospodarki i przyczyniające się m.in. do konsolidacji przemysłu paliwowego, energetycznego, chemicznego czy zbrojeniowego. Stanowią one przyspieszoną przez ten kryzys pragmatyczną korektę myślenia o państwie, rozwoju gospodarczym, a także własności kapitału i przedsiębiorstw.

Strukturalne wskaźniki konwergencji Polski do poziomu rozwoju gospodarczego państw wysoko rozwiniętych powinny bowiem uwzględniać także aktywa finansowe i własność firm. Inaczej trudno zakreślić scenariusz przejścia od roli podwykonawców globalnych korporacji do gospodarki innowacyjnej, charakterystycznej dla państw rozwiniętych. Warto także odnotować, że wśród najbardziej wpływowych państw świata nie znajdziemy takich, w których kluczowe dla ich rozwoju sektory gospodarki kontrolowane są przez kapitał zagraniczny. Zagadnienie to nabiera nowego znaczenia w okresie turbulencji na światowych rynkach, trudniejszego dostępu do kapitału i powrotu agresywnej polityki zagranicznej Rosji, która znacząco pogarsza położenie geopolityczne Europy Środkowej i Wschodniej.

Niemający odpowiednika w państwach zachodnich duży udział inwestorów zagranicznych w gospodarce tego regionu jest często uznawany za kluczowy wyróżnik nowej odmiany „zależnej gospodarki rynkowej”, gospodarki z wiodącą rolą kapitału zagranicznego lub kapitalizmu półperyferyjnego, kontrolowanego przez instytucje unijne i transnarodowe korporacje. W takim ujęciu dominacja międzynarodowych korporacji współistniejących z dużym sektorem państwowym oraz słabym krajowym sektorem prywatnym, ogranicza rozwój rodzimego kapitału i rynkowych klas średnich. Utrwala też podrzędność państwa w międzynarodowym podziale pracy, który redukuje przewagi komparatywne polskiej gospodarki do montażu i produkcji częściowo zestandaryzowanych produktów średniej jakości oraz eksportu artykułów rolno-spożywczych.

Pomimo znaczących zmian gospodarczych w Polsce, utrwalanie takiej sytuacji zwiększałoby ryzyko przejściowego charakteru dobrej koniunktury i możliwość 
wejścia w tzw. pułapkę średniego rozwoju. Rozwój państwa, ze względu na posiadany potencjał aspirującego do roli wykraczającej poza model „pastwiska dla międzynarodowych korporacji” w UE, wymaga zmian instytucjonalnych zwiększających możliwości autonomicznego programowania i realizowania swoich celów na poziomie państwowym, w tym równoważenia zewnętrznych oraz wewnętrznych źródeł finansowania gospodarki.

Rola kapitału zagranicznego w gospodarce państwa, do którego on napływa, zależy w znacznej mierze od stopnia efektywności władz państwowych, jakości instytucji gospodarczych i ich współdziałania z rodzimymi przedsiębiorcami. Rosnący potencjał krajowych spółek tworzy przesłanki do myślenia o polskich firmach jako globalnych inwestorach i ważnych uczestnikach międzynarodowych rynków. Wymaga to określenia sektorów szczególnie ważnych dla gospodarki, które mają szansę stać się naszymi hitami eksportowymi (jak przemysł meblarski, elektrotechnika lub usługi biznesowe), odpowiedniego wsparcia merytorycznego ze strony administracji publicznej - podatkowego, finansowego itd., a także aktywizacji małych i średnich firm tworzących fundamenty silnego rynku wewnętrznego. Możliwości budowania takiego potencjału potwierdzają przykłady polskich przedsiębiorstw odnoszących sukcesy na globalnych rynkach - KGHM Polska Miedź, Getin Holding, LPP, Maspex, Selena lub Solaris ${ }^{57}$.

Szanse na długofalowy rozwój Polski wymagają realizacji dobrze przygotowanych programów podnoszenia nowoczesności i konkurencyjności gospodarki, w tym krajowych przedsiębiorstw, wśród których dominują małe i średnie firmy. Na osiągniętym etapie rozwoju gospodarczego nie wystarcza już „trzecioświatowa” strategia konkurencyjności opartej na zasadzie „niskie koszty, mało nadzoru”, na deregulacji i znoszeniu prawnej ochrony pracowników oraz ograniczaniu podatkowego nacisku państwa. Nie tworzy ona bowiem perspektywy trwałego podnoszenia konkurencyjności polskiej gospodarki, podwyżek wynagrodzeń i wyższych standardów stosunków pracy. W dłuższej perspektywie kapitał zagraniczny powinien dopełniać, a nie zastępować w tym zakresie krajowe przedsiębiorstwa, co jest niezbędne również ze względu na konieczność zmniejszania ryzyka płynącego z otoczenia zewnętrznego.

Zmiany tego rodzaju są przesłanką korzystnej dla Polski ewolucji ekspansji i strategii kapitału zagranicznego, który mógłby zwiększyć swoje zainteresowanie transferem i stosowaniem bardziej zaawansowanych technologii, jeśli do ich stosowania zostaną stworzone korzystniejsze warunki. Członkostwo w UE zwiększyło możliwości wystąpienia efektu synergii, przyspieszyło bowiem realizację działań wzmacniających

${ }^{57}$ K. Rybiński, Go Global. Wywiady z twórcami polskich firm, które zdobyly rynki międzynarodowe, Helion, Gliwice 2014. 
gospodarkę, m.in. poprzez zwiększenie inwestycji w rozwój infrastruktury, nowych technologii i ochrony środowiska oraz otwarcie na dobre praktyki znane z państw wyżej rozwiniętych.

Możliwość efektywnego wykorzystania takich szans wymaga jednak wzmacniania zdolności instytucji publicznych i prywatnych do koordynowania rynkowych, a także pozarynkowych, działań różnych aktorów gospodarczych i społecznych, np. agencji regulacyjnych i antymonopolowych lub dialogu partnerów społecznych ${ }^{58}$. Warunkiem powodzenia jest znacząca poprawa jakości instytucji zarządzających państwem i gospodarką w zakresie prawodawstwa, systemu egzekucji prawa oraz bezpieczeństwa obywateli, których sprawność i wiarygodność obniża koszty transakcyjne, a także sprzyja uruchomieniu aktywności społecznej, która może dynamizować rozwój Polski.

\section{Bibliografia}

Amsden H.A., Kochanowicz J., Taylor L., The Market Meets Its Match. Restructuring the Economies of Eastern Europe, Harvard University Press, Cambridge 1994.

Beck U., Władza i przeciwwładza w epoce globalnej. Nowa ekonomia polityki światowej, tłum. J. Łoziński, Wydawnictwo Naukowe Scholar, Warszawa 2005.

Belka M., Hausner J., Jasiński L.J., Marody M., Zirk-Sadowski M., Polska transformacja w perspektywie integracji europejskiej. EU-monitoring, Friedrich Ebert Foundation, Warszawa 1996.

Berend T.I., Central and Eastern Europe 1944-1993. Detour from the Periphery to the Periphery, Cambridge University Press, Cambridge 1996.

Best H., Cadres into Managers: Structural Changes of East German Economic Elites before and after Reunification, w: Restructuring of the economic elites after state socialism: recruitment, institutions and attitudes, red. D. Lane, G. Lengyel, J. Tholen, ibidem-Verlag, Stuttgart 2007.

Bohle D., Greskovits B., Capitalist Diversity on Europe's Periphery, Cornell University Press, Cornell 2012.

Bohle D., Greskovits B., Neoliberalsm, Embedded Neoliberalism and Neocorporatism: Towards Transnational Capitalism in Central-Eastern Europe, "West European Politics" 2007, vol. 30, no. 3 .

Bukowski M., Szpor A., Śniegocki A., Potencjał i bariery polskiej innowacyjności, Instytut Badań Strukturalnych, Warszawa 2012.

Demokracja w Polsce 2005-2007, red. L. Kolarska-Bobińska, J. Kucharczyk, J. Zbieranek, Instytut Spraw Publicznych, Warszawa 2007.

Domański H., Klasy społeczne, grupy zawodowe, organizacje gospodarcze, Instytut Filozofii i Socjologii PAN, Warszawa 1991.

${ }^{58}$ K. Jasiecki, Kryzys strefy euro jako test modeli kapitalizmu. Co z Polską? w: Polska europejska czy narodowa?, red. M. Jarosz, Instytut Studiów Politycznych PAN - Oficyna Naukowa, Warszawa 2014. 
Domański H., Prokopek A., Podziały terytorialne, globalizacja a nierówności społeczne. Wprowadzenie do modeli wielopoziomowych, Instytut Filozofii i Socjologii PAN, Warszawa 2011.

Drahokoupil J., Globalization and The State in Central and Eastern Europe. The Politics of Foreign Direct Investment, Rutledge, London 2008.

Ekonomia i polityka w kryzysie. Kierunki zmian w teoriach, red. M. Guzek, Uczelnia Łazarskiego - Instytut Studiów Politycznych PAN, Warszawa 2012.

Elites after state socialism. Theories and analysis, red. J. Higley, G. Lengyel, Rowman \& Littlefield Publishers, Boston 2000.

Eyal G., Szelenyi I., Townsley E., Making Capitalism Without Capitalists: Class Formation and Elite Struggles in Post-Communist Europe, Verso, London 1998.

Gorynia M., Strategie firm polskich wobec ekspansji inwestorów zagranicznych, Państwowe Wydawnictwo Ekonomiczne, Warszawa 2005.

Huntington S.P., Who are we? America's Great Debate, Simon \& Schuster, London 2004.

Inwestycje zagraniczne w Polsce, red. J. Chojna, Instytut Badań Rynku, Konsumpcji i Koniunktur, Warszawa 2010.

Jasiecki K., Elita biznesu w Polsce. Drugie narodziny kapitalizmu, Instytut Filozofii i Socjologii PAN, Warszawa 2002.

Jasiecki K., Kapitalizm po polsku. Między modernizacja a peryferiami Unii Europejskiej, Instytut Filozofii i Socjologii PAN, Warszawa 2013.

Jasiecki K., Kryzys strefy euro jako test modeli kapitalizmu. Co z Polska?? w: Polska europejska czy narodowa?, red. M. Jarosz, Instytut Studiów Politycznych PAN - Oficyna Naukowa, Warszawa 2014.

Jasiecki K., Od euroentuzjazmu do eurosceptycyzmu?, w: Transformacja Elity Społeczeństwo, red. M. Jarosz, Instytut Studiów Politycznych PAN, Warszawa 2007.

Kapitat zagraniczny w prywatyzacji, red. M. Jarosz, Instytut Studiów Politycznych PAN, Warszawa 1996.

Kenworthy L., Institutions, Wealth, and Inequality, w: The Oxford Handbook of Comparative Institutional Analysis, red. G. Morgan, J. Campbell, C. Crouch, O. Kay Pedersen, R. Whitley, Oxford University Press, Oxford 2010.

King L.P., Central European Capitalism in Comparative Perspective, w: Beyond Varieties of Capitalism. Conflict, Contradictions, and Complementarities in the European Economy, red. B. Hancké, M. Rhodes, M. Thatcher, Oxford University Press, Oxford 2007.

King L.P., Szelenyi I., Post-Communist Economic Systems, w: The Handbook of Economic Socio$\log y$, red. J.N. Smelser, R. Swedberg, Princeton University Press, Princeton 2005.

Kochanowicz J., Transformacja polska w świetle socjologii historycznej. Między Trzecim Światem a państwem opiekuńczym, „Kultura i Społeczeństwo” 1998, nr 1(42).

Krasnodębski Z., Postkomunistyczna etyka i duch kapitalizmu, w: System wartości i norm społecznych podstawą rozwoju Polski, Instytut Badań nad Gospodarką Rynkową, Gdańsk 2005.

Kurs na innowacje. Jak wyprowadzić Polskę z rozwojowego dryfu?, red. J. Hausner, Fundacja Gospodarki i Administracji Publicznej, Kraków 2012. 
Lane D., Myant M., Varieties of Capitalism in Post-Communist Countries, Palgrave Macmillan, New York 2007.

Mach B.W., Jakość demokracji a struktura społeczna: uwagi koncepcyjne i ilustracje empiryczne, w: Jakość naszej demokracji. Społeczno-kulturowe podstawy polskiego życia publicznego, red. B.W. Mach, Instytut Studiów Politycznych PAN, Collegium Civitas, Warszawa 2012.

Mann M., Riley D., Explaining macro-regional trends in global income inequalities, 1950-2000, "Socio-Economic Review" 2007, no. 5.

Nolke A., Vliegenthart A., Enlarging The Varieties of Capitalism: The Emergence of Dependent Market Economies in East Central Europe, "World Politics" 2009, no. 4.

Offe C., Designing Institutions in East European Transitions, w: The Theory of Insitutional Design, red. R.E. Goodwin, G.H. Brennan, Cambridge University Press, Cambridge 1996.

Oręziak L., OFE. Katastrofa prywatyzacji emerytur w Polsce, Książka i Prasa, Warszawa 2014.

Perczyński M., Międzynarodowe stosunki gospodarcze Polski w okresie otwierania się i transformacji gospodarki, w: Dynamika transformacji polskiej gospodarki, red. M. Belka, W. Trzeciakowski, Poltext, Warszawa 1997.

Polska 2030. Wyzwania rozwojowe, red. M. Boni, Kancelaria Prezesa Rady Ministrów, Warszawa 2009.

Polskie grupy kapitałowe. Perspektywa europejska, red. B. Wawrzyniak, Wydawnictwo Wyższej Szkoły Przedsiębiorczości i Zarządzania im. Leona Koźmińskiego, Warszawa 2002.

Rodrik D., The Globalization Paradox. Why Global Markets, States, and Democracy Can't Coexist, Oxford University Press, Oxford 2011.

Różański J., Przedsiębiorstwa zagraniczne w Polsce. Rozwój. Finansowanie. Ocena, Polskie Wydawnictwo Ekonomiczne, Warszawa 2010.

Rzemieślnicy i biznesmeni. Właściciele małych i średnich przedsiębiorstw, red. J. Gardawski, Wydawnictwo Naukowe Scholar, Warszawa 2013.

Sassen S., Globalizacja. Eseje o nowej mobilności ludzi i pieniędzy, tłum. J. Tegnerowicz, Uniwersytet Jagielloński, Kraków 2007.

Sklair L., The Transnational Capitalist Class, Blackwell Publisher, Malden 2003.

Sosnowska A., Teorie zmiany i rozwoju społecznego a zmiany w Europie Wschodniej. O potrzebie perspektywy globalnej, „Kultura i Społeczeństwo” 1998, nr 1(42).

Standing G., Prekariat. Nowa niebezpieczna klasa, Wydawnictwo Naukowe PWN, Warszawa 2014.

Staniszkis J., Postkomunizm. Próba opisu, słowo/obraz terytoria, Gdańsk 2001.

Szahaj A., Kapitalizm drobnego druku, Książka i Prasa, Warszawa 2014.

Szałamacha P., IV Rzeczpospolita pierwsza odsłona. Dlaczego się nie udało, co trzeba zrobić, Zysk i S-ka, Poznań 2009.

Szczepański M.S., Ani Elizjum, ani Hades. Piętnastolecie polskiej transformacji w perspektywie socjologicznych teorii zmiany, w: Współczesne społeczeństwo polskie. Dynamika zmian, red. J. Wasilewski, Wydawnictwo Naukowe Scholar, Warszawa 2006.

Szelągowska A., Kapitał zagraniczny w polskich bankach, Poltext, Warszawa 2004. 
Szelenyi I., Treinman D., Wnuk-Lipiński E., Elity w Polsce, w Rosji i na Wegrzech. Wymiana czy reprodukcja, Instytut Studiów Politycznych PAN, Warszawa 1995.

Szomburg J., Atrakcyjna Polska, czyli jaka?, „Rzeczpospolita”, 01.03.2007.

Wasilewski J., Elitystyczne wyjaśnienia wschodnioeuropejskich demokratyzacji, w: Populizm a demokracja, red. R. Markowski, Instytut Studiów Politycznych PAN, Warszawa 2004.

Wnuk-Lipiński E., Opinia w sprawie prywatyzacji gospodarki narodowej, w: $Z$ archiwów OKP. Ekspertyzy zespołu doradców socjologicznych Obywatelskiego Klubu Parlamentarnego, Wydawnictwo Naukowe PWN, Warszawa 1989-1990.

Zarycki T., Peryferie. Nowe ujęcia zależności centro-peryferyjnych, Wydawnictwo Naukowe Scholar, Warszawa 2009.

Zorska A., Ku globalizacji? Przemiany w korporacjach transnarodowych i w gospodarce światowej, Wydawnictwo Naukowe PWN, Warszawa 2002.

Żukowski T., Potęga tożsamości, w: System wartości i norm społecznych podstawą rozwoju Polski, Instytut Badań nad Gospodarką Rynkową, Gdańsk 2005. 
